\title{
HEEL LESIONS OF RHEUMATOID ARTHRITIS
}

BY

\author{
E. G. L. BYWATERS \\ From the Special Unit for Juvenile Rheumatism, Canadian Red Cross Memorial Hospital, Taplow, Bucks, \\ and the Department of Medicine, Postgraduate Medical School of London
}

(RECEIVED FOR PUBLICATION DECEMBER 16, 1953)

Two lesions affecting the heel in rheumatoid arthritis have received little or no attention of recent years: one involves the plantar surface of the calcaneus and the calcaneal spur, and the other the synovial bursa between the insertion of the Achilles tendon into the calcaneus and the calcaneus itself. This note is designed primarily to draw attention to the sub-Achilles lesion, since it may be the presenting sign of rheumatoid arthritis and is often a major complaint: secondarily, to point out that the plantar surface of the calcaneus is often actively involved in rheumatoid arthritis and to indicate the nature of the involvement.

Normal Anatomy.-Normally (Fig. 1a, opposite), the Achilles tendon is inserted about $2 \mathrm{~cm}$. below the upper surface of the calcaneus; the latter is covered with fibro-cartilage opposite the free tendon (Fig. 1b), and the bursal space is lined over the tendon by a thin synovium, and at its margins by synovium-covered fatty pads (Fig. 1c); there is a very small amount of viscous fluid. With advancing age, some cartilage degeneration occurs (Fig. 2); this is well described by Rossler (1896) on the basis of 225

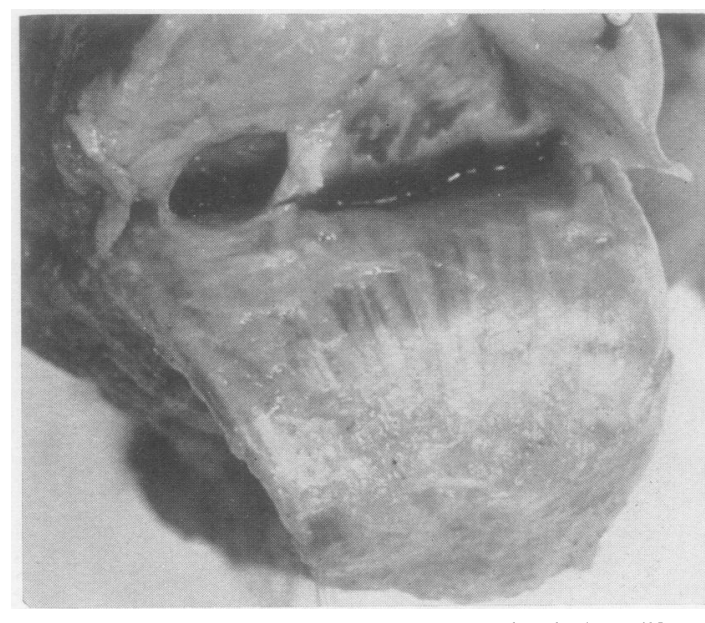

Fig. 2.-Bone, showing cartilage degeneration in later life. bursae examined from about 140 cadavers of

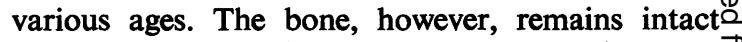
throughout life, and $x$ rays show a smooth strong $\overrightarrow{\underline{O}}$ cortical layer.

The plantar surface of the os calcaneus (Fig. 3) is

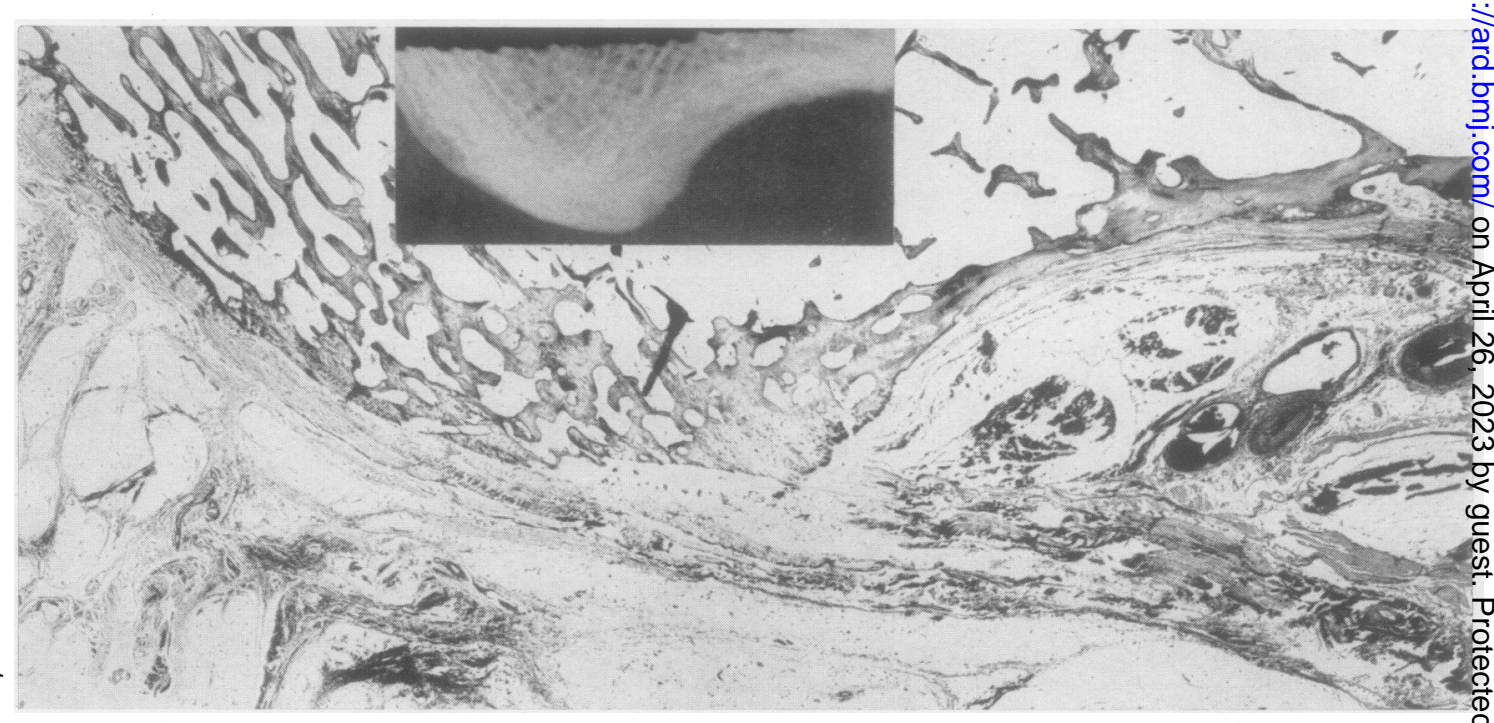

Fig. 3.-Plantar surface of calcaneus $(\times 7)$ in normal female aged 36, with $x$ ray inset. Note smooth cortical bone. 


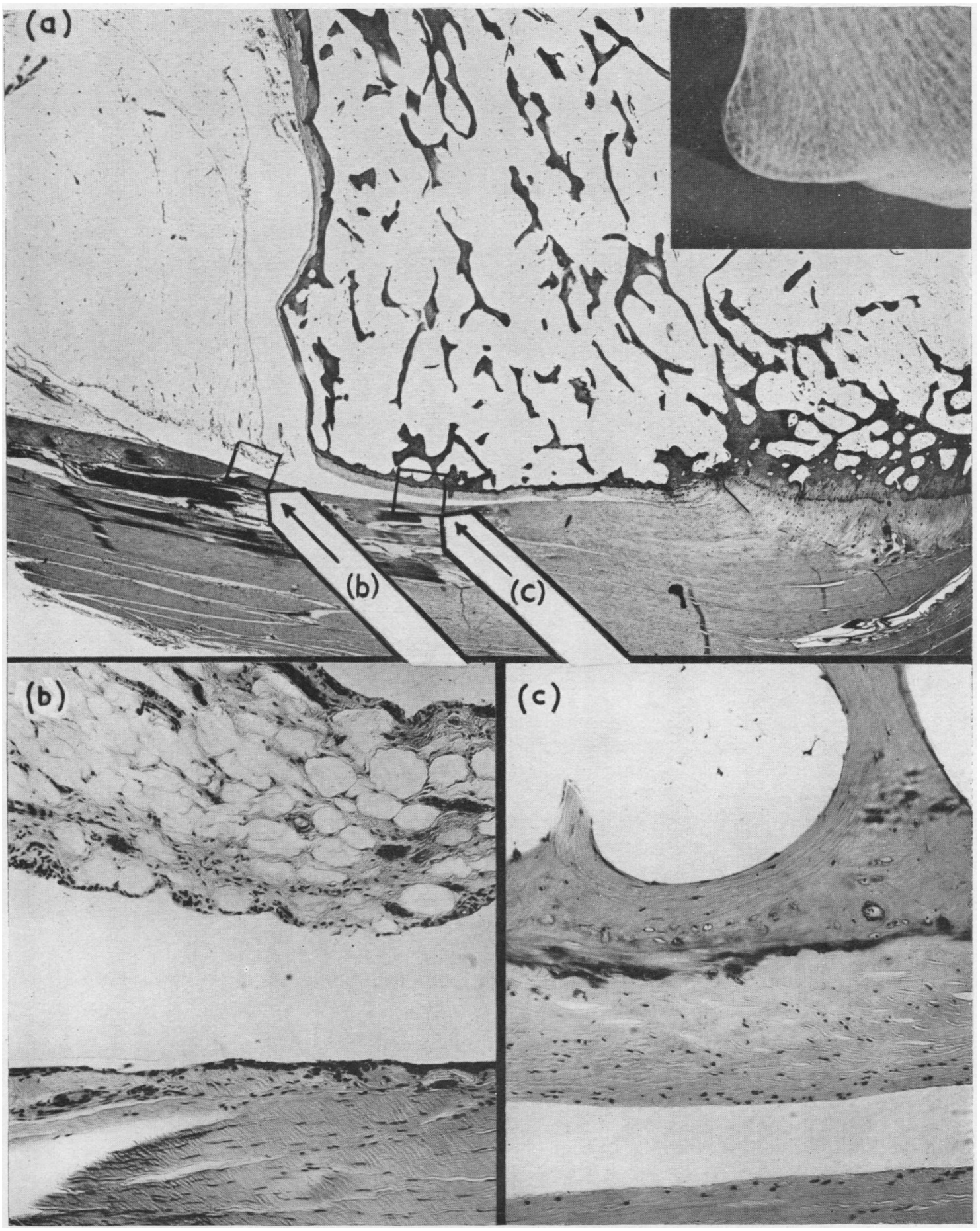

Fig. 1.-Achilles tendon insertion in female aged 36 (with carcinoma of the cervix).

(a) Microphotograph of sagittal section $(\times 7)$ with $x$ rays inset.Note T-shaped bursal cavity.

(b) High-power view of marked area showing intra-bursal fat pad and synovial cells covering it $(\times 130)$.

(c) High-power view of marked area of fibro-cartilage covering bone $(\times 130)$. 
covered by dense periosteum into which are inserted posteriorly the Achilles tendon and anteriorly the plantar aponeurosis. In between, the heel rests on a cushioned pad of fat interlaced with strong fascial sheets. Plantar spurs are seen in many people, the incidence increasing with age, without any complaint relating thereto; they consist of an extension of bone into the periosteal insertion of the plantar aponeurosis.

Incidence.-In the past 7 years 22 patients have complained of pain or swelling, or both, in the heel; in all except one radiological changes were visible. All, except one with synovial chondromatosis of the sub-Achilles bursa, were suffering from rheumatoid arthritis, as judged either by the actual presence at that time of other clinical and radiological criteria or by their development in the next few years. The incidence is probably of the order of 2-3 per cent., since, in an unselected series of 250 patients with rheumatoid arthritis, seen between 1939 and 1948 and followed to the present time (Dresner and Bywaters, 1953), six complained of painful heels and showed these lesions radiologically.* These six are included in the 21 mentioned above. Two others of the 21 in the series showed plantar-spur formation and ossification of the Achilles tendon only, without erosions, and these were not considered further. The Table (opposite) gives details of the group of nineteen cases with rheumatoid arthritis, radiological erosions being seen in eighteen of them. It will be noted that nine are female and ten male, a reversal of the usual sex-ratio. The patients' ages at the time of the heel lesion ranged between 21 and 65 years (usually in the $30 \mathrm{~s}$ and $40 \mathrm{~s}$ ). The erythrocyte sedimentation rate was raised at the time in eleven of the nineteen and normal in eight.

\section{Clinical Features}

Sometimes the complaint of heel tenderness came within a few months of the onset of rheumatoid arthritis (four patients), and might even be one of the presenting symptoms, as in Cases 1 and 2.

Case 2, male, aged 32, complained of pain in back, feet, and ankles in July, 1945. Examination one month from onset revealed pain and swelling in both ankles, the left knee, and the metatarsophalangeal joint of both big toes. There was tenderness over both Achilles tendons and soreness of the plantar surface of both heels. The erythrocyte sedimentation rate was $105 \mathrm{~mm}$./hr (Westergren).

One year later he was back at work, with no pain in the heels but some in the forefoot. Improvement continued and the erythrocyte sedimentation rate fell to

\footnotetext{
* Those without complaint were not $x$-rayed.
}

$25 \mathrm{~mm}$. in 1947, and to $18 \mathrm{~mm}$. in 1950, but there was occasionally some pain in both heels and tenderness $\frac{\nabla}{n}$. over the os calcis.

Fig. 4 shows the appearance of erosions beneath both $\vec{F}$ Achilles tendons and beneath the heels; these had $\stackrel{\text { of }}{+}$ healed on the left by 1950, but left spurs not present $\bar{C}$ originally.

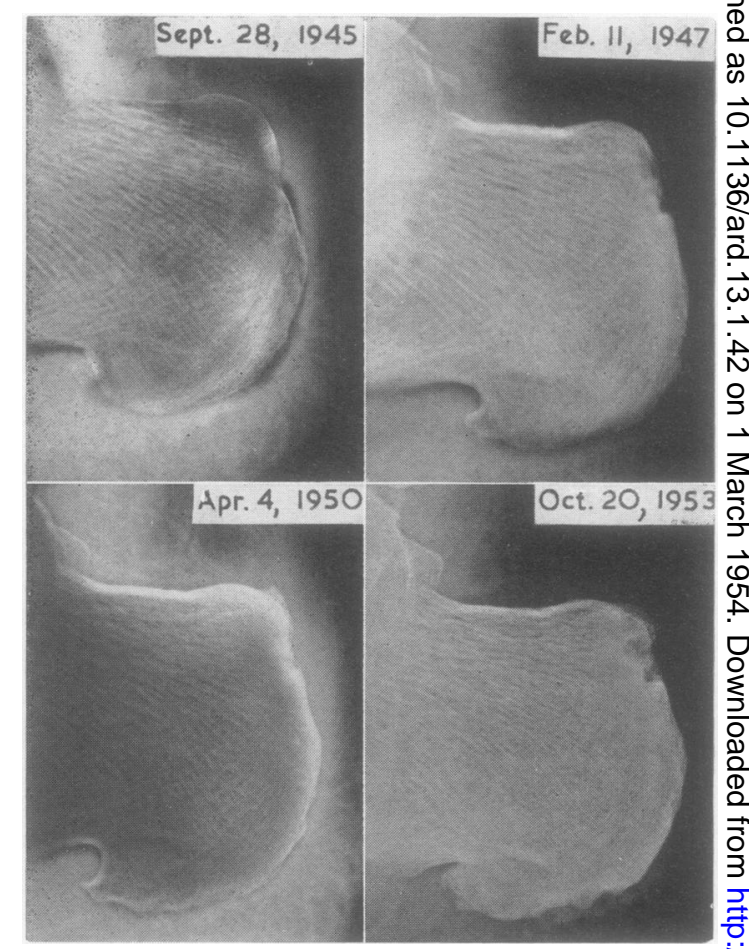

Fig. 4.-Case 2, heels: at onset, and during the following 8 years. Note bilateral sub-Achilles and plantar erosions.

The sub-Achilles bursal lesion produces pain on walking and on pressure of the shoe: tenderness is elicited by pressure on the posterior surface of the calcanean bone at the insertion of the tendon. This 음 tendon itself appears to be broader and flatter than $D$ usual or may present a localized swelling near its insertion. Beneath it is felt a large fluctuant mass, $N$ occupying the space between tendon and ankle and protruding on either side of the tendon. Attempts 0 to withdraw fluid by needling were unsuccessful in $\omega$ three cases. These lesions were bilateral in two cases; Fig. 5 (opposite) shows the appearances in Case 9.0 In a number of cases the lesions were accompanied $\mathbb{D}$ by plantar calcaneal erosions (Table).

The plantar lesions manifest themselves with pain $\underset{0}{0}$ and tenderness, but without swelling.

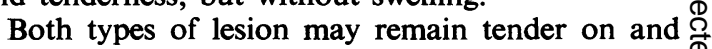
off for years, but more usually the tenderness and the $\stackrel{\mathbb{Q}}{\square}$ 
TABLE

PARTICULARS OF NINETEEN PATIENTS WITH RHEUMATOID ARTHRITIS

\begin{tabular}{|c|c|c|c|c|c|c|c|c|c|c|c|c|c|}
\hline \multirow{3}{*}{$\begin{array}{l}\text { Case } \\
\text { No. }\end{array}$} & \multirow{3}{*}{$\begin{array}{c}\text { Hospital } \\
\text { No. }\end{array}$} & \multirow{3}{*}{ Sex } & \multirow{3}{*}{$\begin{array}{l}\text { Age } \\
\text { (yrs) }\end{array}$} & \multirow{3}{*}{$\begin{array}{c}\text { Differential } \\
\text { Sheep-cell } \\
\text { Agglutination } \\
\text { Titre }\end{array}$} & \multirow{3}{*}{$\begin{array}{c}\text { Erythrocyte } \\
\text { Sedimentation } \\
\text { Rate } \\
\text { (Westergren) }\end{array}$} & \multirow{3}{*}{$\begin{array}{l}\text { Nodules } \\
(\mathrm{X} \text { or } \mathrm{O})\end{array}$} & \multirow{2}{*}{\multicolumn{2}{|c|}{$\begin{array}{c}\text { Affected } \\
\text { Tarsus or } \\
\text { Metatarso- } \\
\text { phalangeal }\end{array}$}} & \multirow{3}{*}{$\begin{array}{c}\text { Time since } \\
\text { Onset of } \\
\text { Heel Lesions } \\
\text { (yrs) }\end{array}$} & \multicolumn{4}{|c|}{ Location of Lesions } \\
\hline & & & & & & & & & & \multicolumn{2}{|c|}{ Sub-Achilles } & \multicolumn{2}{|c|}{ Plantar } \\
\hline & & & & & & & $\mathbf{R}$ & $\mathbf{L}$ & & $\mathbf{R}$ & $\mathbf{L}$ & $\mathbf{R}$ & $\mathbf{L}$ \\
\hline $\begin{array}{r}1 \\
2 \\
* 3 \\
4 \\
5 \\
6 \\
7 \\
8 \\
9 \\
10 \\
11 \\
12 \\
13 \\
14 \\
15 \\
16 \\
17 \\
18 \\
19\end{array}$ & $\begin{array}{lr}\text { T. } & 07468 \\
\text { H. } & 57175 \\
\text { T. } & 27636 \\
\text { T. } & 20123 \\
\text { H. } & 59756 \\
\text { T. } 18367 \\
\text { T. } 17264 \\
\text { T. } 23117 \\
\text { H. } 101980 \\
\text { H. } 72396 \\
\text { T. } 16352 \\
\text { H. } 131886 \\
\text { H. } 54262 \\
\text { H. } 33924 \\
\text { T. } 10551 \\
\text { H. } 74648 \\
\text { H. } 148476 \\
\text { T. } 24020 \\
\text { H. } 68196\end{array}$ & $\begin{array}{l}\mathbf{M} \\
\mathbf{M} \\
\mathbf{F} \\
\mathbf{M} \\
\mathbf{F} \\
\mathbf{M} \\
\mathbf{M} \\
\mathbf{M} \\
\mathbf{F} \\
\mathbf{M} \\
\mathbf{F} \\
\mathbf{F} \\
\mathbf{F} \\
\mathbf{M} \\
\mathbf{F} \\
\mathbf{M} \\
\mathbf{F} \\
\mathbf{M} \\
\mathbf{F}\end{array}$ & $\begin{array}{l}40 \\
32 \\
65 \\
39 \\
56 \\
21 \\
45 \\
24 \\
35 \\
21 \\
43 \\
35 \\
48 \\
46 \\
50 \\
39 \\
40 \\
25 \\
33\end{array}$ & $\begin{array}{ll}1 & : 32 \\
1 & : 8 \\
1 & : 32 \\
1 & : 8 \\
1 & : 256 \\
1 & -8 \\
1 & \vdots 1 \\
1 & : 16 \\
1 & -4 \\
1 & 4 \\
1 & \vdots 128 \\
1 & : 32 \\
1 & -16 \\
1 & : 16 \\
1 & \vdots 2 \\
1 & \vdots 4 \\
1 & : 32\end{array}$ & $\begin{array}{r}31 \\
105 \\
37 \\
6 \\
36 \\
15 \\
21 \\
15 \\
35 \\
10 \\
27 \\
33 \\
43 \\
100 \\
6 \\
102 \\
18 \\
9 \\
12\end{array}$ & $\begin{array}{l}\mathbf{X} \\
\mathbf{O} \\
\mathbf{O} \\
\mathbf{O} \\
\mathbf{X} \\
\mathbf{O} \\
\mathbf{X} \\
\mathbf{O} \\
\mathbf{O} \\
\mathbf{O} \\
\mathbf{O} \\
\mathbf{X} \\
\mathbf{X} \\
\mathbf{X} \\
\mathbf{O} \\
\mathbf{X} \\
\mathbf{X} \\
\mathbf{O} \\
\mathbf{X}\end{array}$ & $\begin{array}{l}\mathbf{R} \\
\mathbf{R} \\
\mathbf{O} \\
\mathbf{R} \\
\mathbf{O} \\
\mathbf{R} \\
\mathbf{R} \\
\mathbf{O} \\
\mathbf{R} \\
\mathbf{R} \\
\mathbf{R} \\
\mathbf{R} \\
\mathbf{R} \\
\mathbf{R} \\
\mathbf{O} \\
\mathbf{R} \\
\mathbf{R} \\
\mathbf{R} \\
\mathbf{R}\end{array}$ & $\begin{array}{l}\text { L } \\
\mathbf{L} \\
\mathbf{L} \\
\mathbf{L} \\
\mathbf{L} \\
\mathbf{L} \\
\mathbf{L} \\
\mathbf{O} \\
\mathbf{L} \\
\mathbf{L} \\
\mathbf{L} \\
\mathbf{L} \\
\mathbf{L} \\
\mathbf{L} \\
\mathbf{O} \\
\mathbf{L} \\
\mathbf{L} \\
\mathbf{O} \\
\mathbf{L}\end{array}$ & $\begin{array}{l}0 \\
1 / 12 \\
3 / 12 \\
4 / 12 \\
6 / 12 \\
1 \\
2 \\
2 \\
2 \frac{1}{2} \\
3 \\
3 \\
5 \\
5 \\
6 \\
9 \\
10 \\
11 \\
12 \\
13\end{array}$ & $\begin{array}{l}\mathbf{O} \\
\mathbf{R} \\
\mathbf{R} \\
\mathbf{O} \\
\mathbf{R} \\
\mathbf{O} \\
\mathbf{O} \\
\mathbf{O} \\
\mathbf{R} \\
\mathbf{R} \\
\mathbf{O} \\
\mathbf{R} \\
\mathbf{R} \\
\mathbf{O} \\
\mathbf{O} \\
\mathbf{R} \\
\mathbf{R} \\
\mathbf{O} \\
\mathbf{R}\end{array}$ & $\begin{array}{l}\mathbf{O} \\
\mathbf{L} \\
\mathbf{O} \\
\mathbf{L} \\
\mathbf{O} \\
\mathbf{L} \\
\mathbf{L} \\
\mathbf{O} \\
\mathbf{O} \\
\mathbf{O} \\
\mathbf{L} \\
\mathbf{O} \\
\mathbf{O} \\
\mathbf{L} \\
\mathbf{L} \\
\mathbf{O} \\
\mathbf{O} \\
\mathbf{L} \\
\mathbf{L}\end{array}$ & $\begin{array}{l}\mathbf{R} \\
\mathbf{R} \\
\mathbf{O} \\
\mathbf{O} \\
\mathbf{O} \\
\mathbf{O} \\
\mathbf{R} \\
\mathbf{R} \\
\mathbf{O} \\
\mathbf{O} \\
\mathbf{O} \\
\mathbf{O} \\
\mathbf{R} \\
\mathbf{O} \\
\mathbf{O} \\
\mathbf{R} \\
\mathbf{O} \\
\mathbf{O} \\
\mathbf{O}\end{array}$ & $\begin{array}{l}\text { L } \\
\text { L } \\
\text { O } \\
\text { L } \\
\text { O } \\
\text { O } \\
\mathbf{L} \\
\mathbf{L} \\
\text { O } \\
\text { O } \\
\text { O } \\
\mathbf{L} \\
\mathbf{L} \\
\mathbf{O} \\
\mathbf{O} \\
\mathbf{L} \\
\mathbf{O} \\
\mathbf{O} \\
\mathbf{O}\end{array}$ \\
\hline
\end{tabular}

* No bony $x$-ray change.

swelling disappear after a few years leaving radiological but no functional residua. In this they differ from the lesions of diarthrodial joints. It may be noted (Table) that, in the three cases where there is unilateral metatarsal or tarsal involvement, the associated sub-Achilles lesion is also unilateral but on the opposite side. This may be coincidence, but it may possibly represent a localization due to extra use; in a similar way we have often noticed that where olecranal nodules are unilateral, the opposite shoulder is usually affected but not the ipsilateral one.

The Table also shows that there is little correlation between the presence of plantar erosions and either nodule formation elsewhere or a raised sheep-cell agglutination titre.

Radiology.-The earliest radiological sign of a sub-Achilles lesion is in the soft tissues. The tendon becomes thicker on lateral view and the clear space beneath it, normally occupied by radio-translucent fat, becomes opaque owing to the presence of inflammatory cells, fluid, and blood vessels (Case 5, Fig. 6, overleaf).

At the same time, a rarefaction appears in the subjacent bone, and the sharply defined layer of subchondral cortical bone becomes less well defined and fuzzy. Finally, well-marked erosions, maximal just above the upper end of the insertion of the tendon, appear; this change may be quite rapid, as in Case 11 (Fig. 7, overleaf), where the interval between the first and second $x$ rays was only 4 months, the first picture being taken within 4 weeks of the onset of pain and swelling. After a period of years, healing sets in, which is witnessed radiologically by remineralization of the bone and disappearance of the abnormal soft tissue thickening.

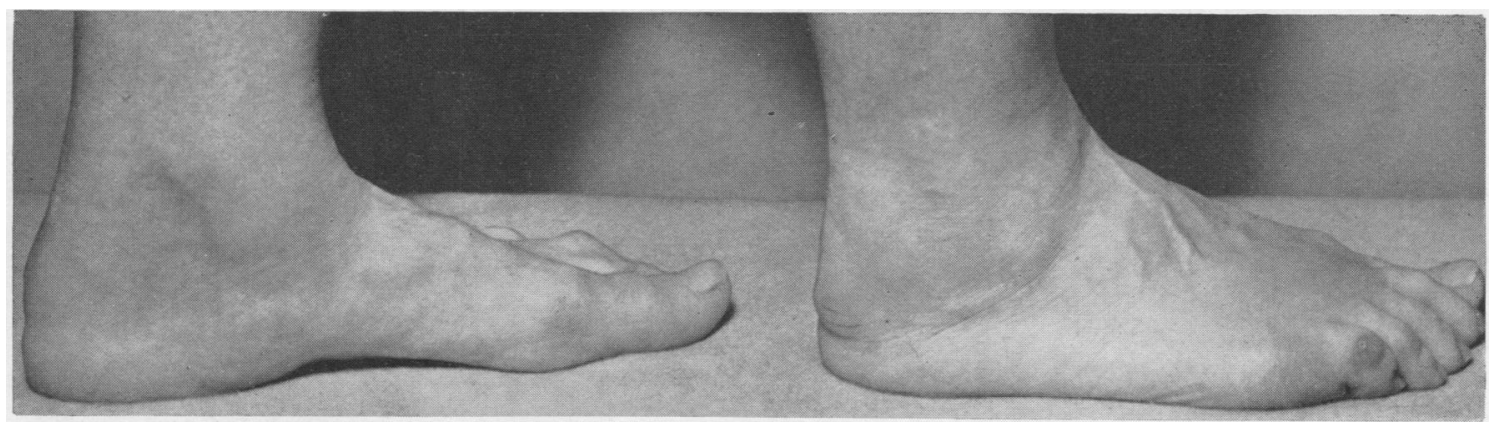

Fig. 5.-Case 9, bilateral swelling in, under, and to each side of Achilles tendon, present for 1 month. 

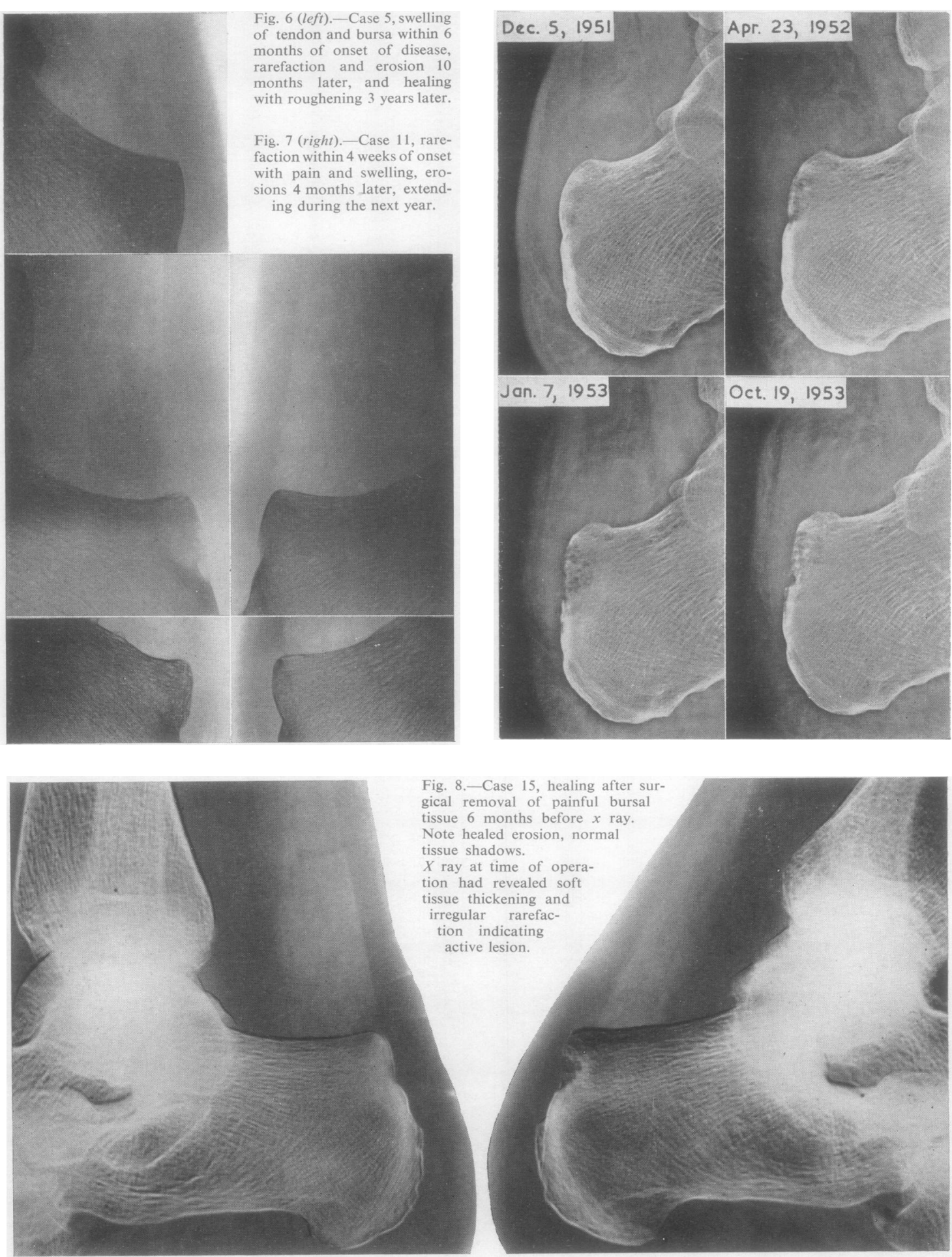

Fig. 8,- Case 15, healing after surgical removal of painful bursal issue 6 months before $x$ ray. shadows.

ray at time of operation had revealed soft ssue thickening and regular rarefac tion indicating ive lesion.

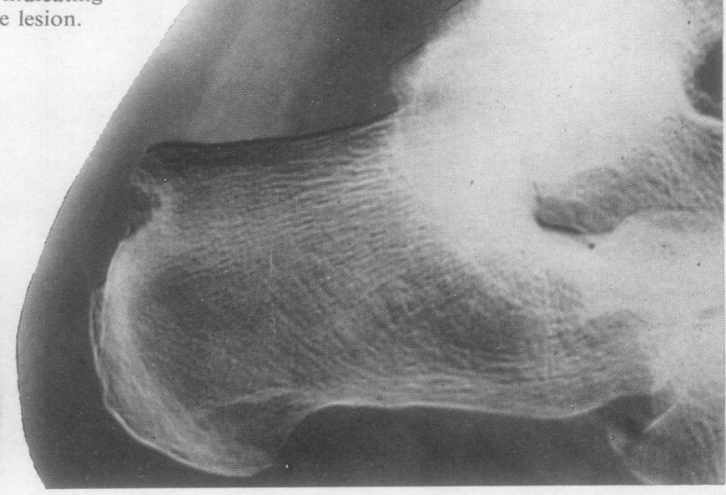




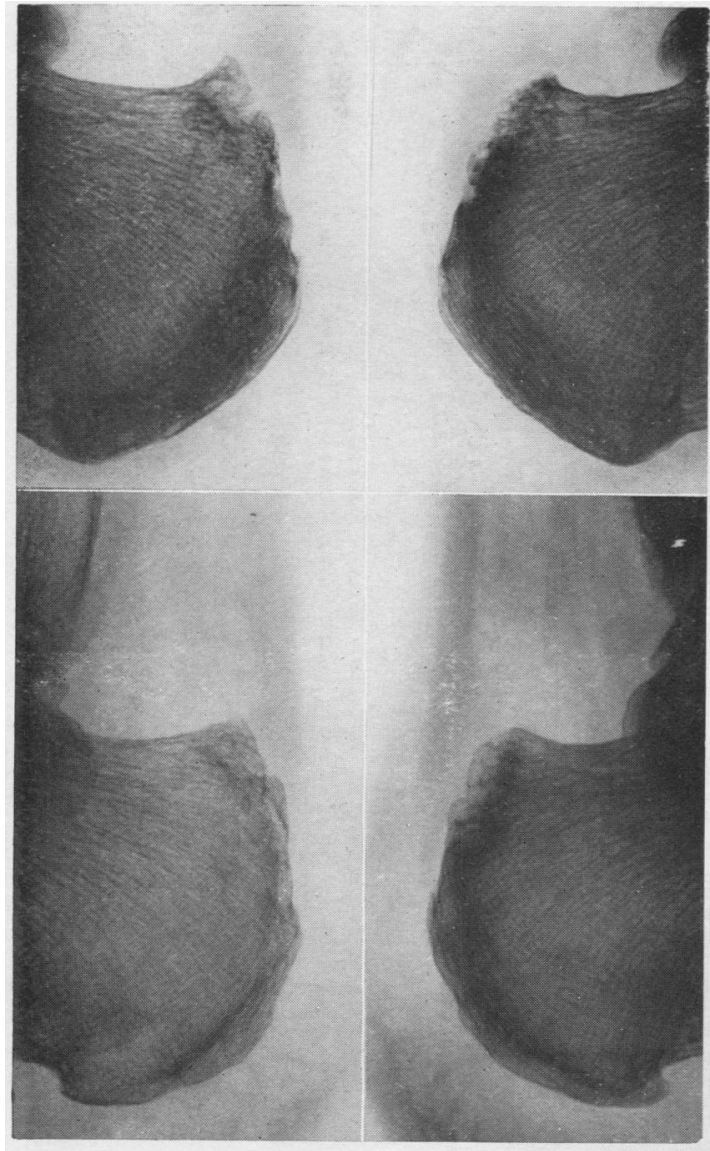

behind the spur backwards; they appear first as rarefactions and finally as clear spaces, somewhat moth-eaten in appearance.

The plantar spur is usually involved and lengthened (Case 13, Fig. 10), or it may appear for the first time as a result of this process.

The last figure illustrates well the major destruction that may occur to a depth of apparently up to $1 \mathrm{~cm}$. into the bone.

Pathology.-Biopsy has been performed on three patients and an autopsy examination on one. The biopsies showed a mass of rheumatoid granulation tissue, hyperplastic membrane, and large collections of plasma cells and lymphocytes embedded in a mass of myxomatous connective tissue.

In some areas the synovial membrane bore some resemblance to the later stages of a rheumatoid nodule, where the palisade layer comes to lie on

Fig. 9.-Case 19, erosions of whole subchondral surface and development of small spurs between May, 1951, and June, 1952.

Fig. 10.-Case 13, progressive destruction of plantar surface of bone between August and November, 1948.

A permanent erosion scar is usually left as in Case 15 (Fig. 8), although in some patients no actual defect remains and the only sign of previous damage is a roughening of the cortical bony outline (Fig. 6). In others, defects occur all along the sub-tendinous surface from insertion up to the free edge (Case 19), (Fig. 9.)

The plantar lesions consist solely of an erosion of bone, often occurring over an area of $1-2 \mathrm{~cm}$. from the joint

Aug. 24,1948
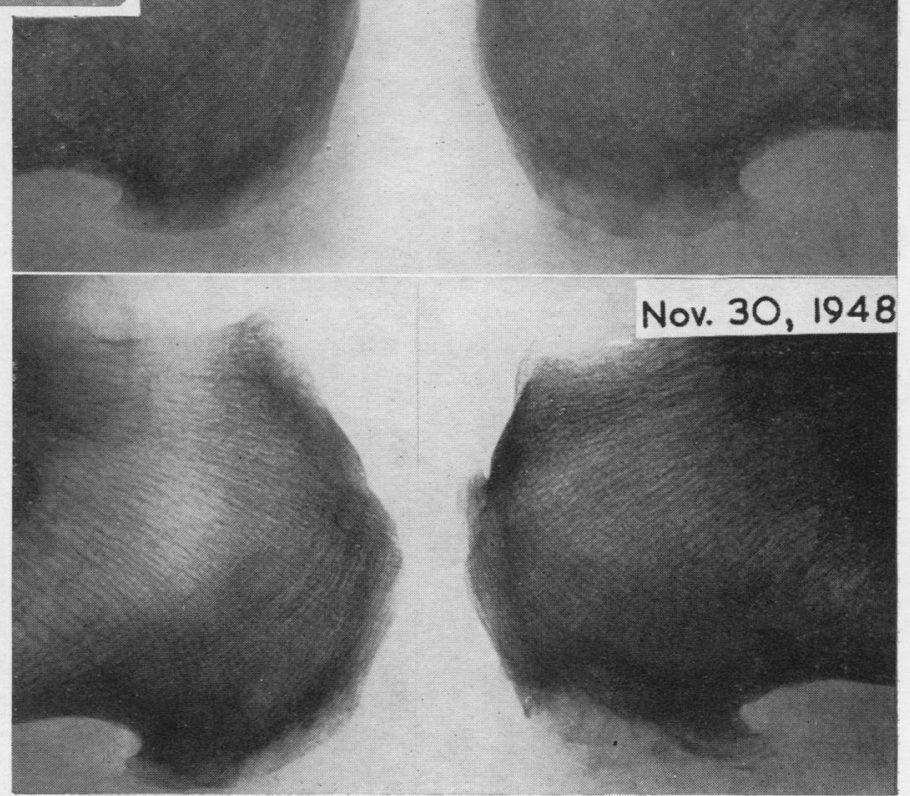


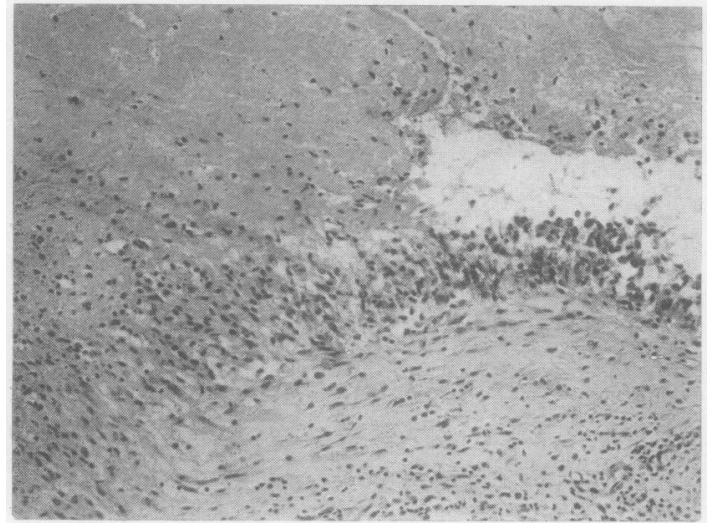

Fig. 11.-Case 15, Photomicrograph of bursal lining cells. Haematoxylin and eosin $(\times 100)$.

Fig. 12.-Case 16, Photomicrograph of sub-Achilles erosion and bursal obliteration in healed stage (reticulin $\times 7$ ) with $x$ ray of same area $(\times 2 \cdot 5)$ inset.

the free surface of a cavity (Case 15, Fig. 11).

The autopsy specimen was from Case 16, a man dying with cor pulmonale, who had had rheumatoid arthritis for 13 years, and 3 years before death developed soft tissue swelling and erosion of the right sub-Achilles area and both plantar regions of the os calcis (Figs 12 and 13). Dissection showed complete obliteration of the sub-Achilles space. A sagittal section is compared with the $x$ ray of a sagittal slice at death, and with the in vivo lateral $x$ ray taken 3 years before. It shows that the acute inflammatory process has subsided, leaving residual blood vessels of the fatty pad,
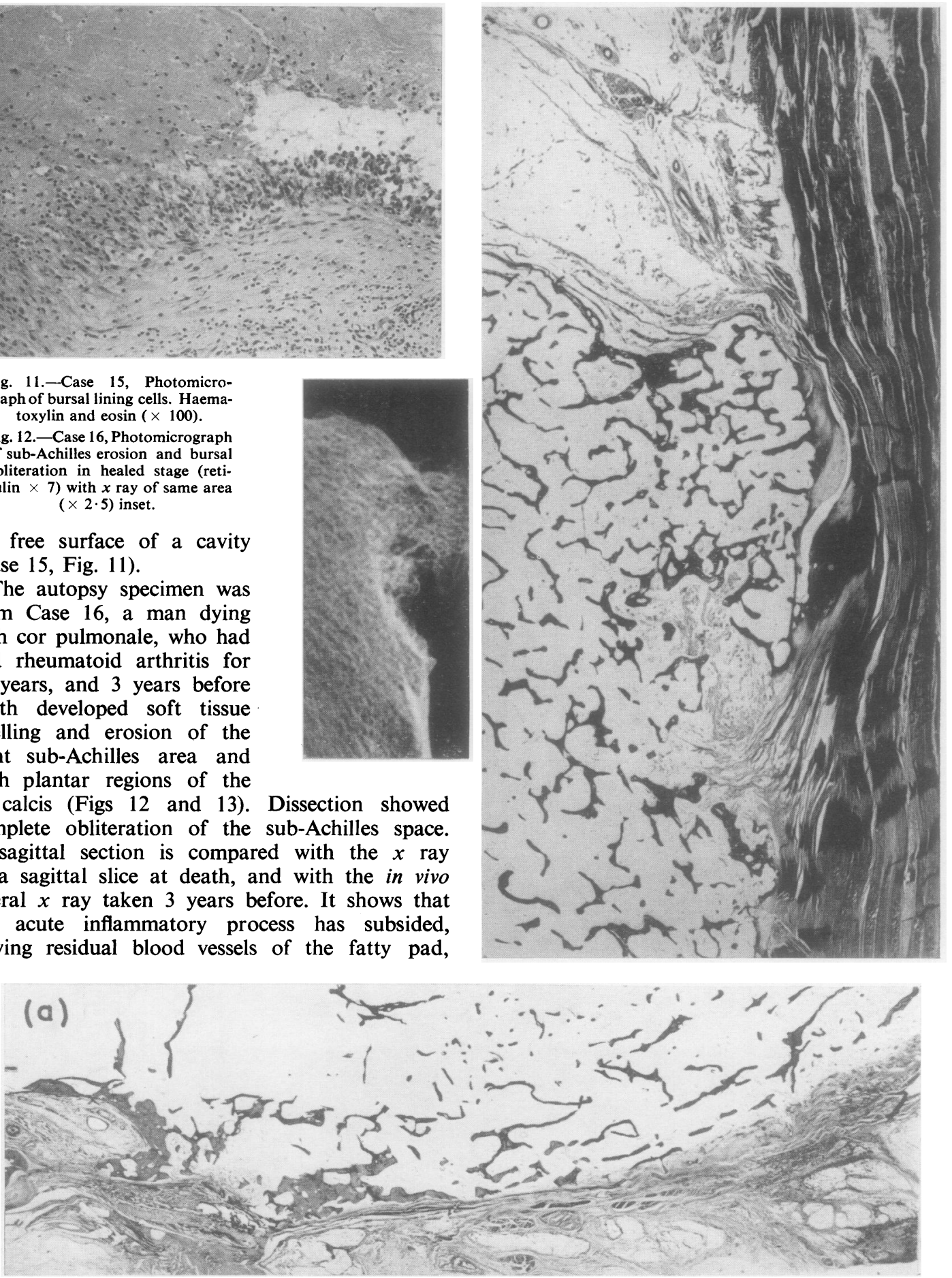

Fig. 13(a).-Case 16

Photomicrograph of plantar surface of calcaneus, fibrinoid lattice work, and bone erosion. Haematoxylin and eosin $\times 5$ ). 


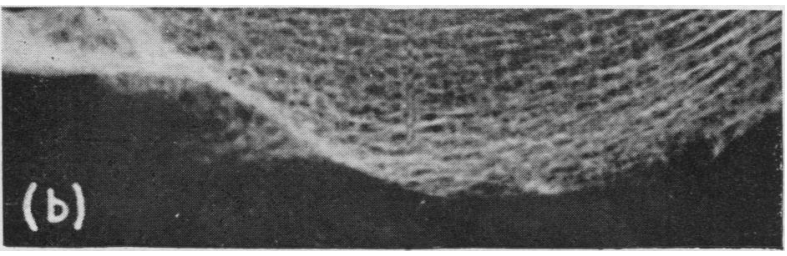

Fig. 13(b).-Case $16, x$ ray $(\times 2-5)$.

obliteration of the space, and a healed erosion of bone above the upper part of the tendon insertion, with loss of cartilage except at this site.

Dissection of the plantar surface of both right and left bones revealed a hyperaemic and rough (gritty) periosteal layer in this region overlaid by and densely adherent to an opaque yellow layer between it and the cushion of fat. Microscopically (Fig. 13a) this layer is seen to be fibrinoid and arranged in a lattice-work, invading bone from which it is separated by a vascular layer of cellular proliferation. It is sometimes arranged in a palisade (Fig. 14) and

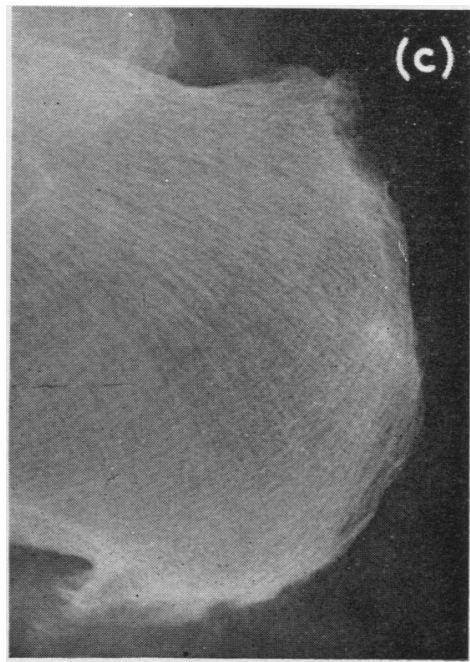

Fig. 13(c).-Case $16, x$ ray 3 years earlier, showing active absorption.

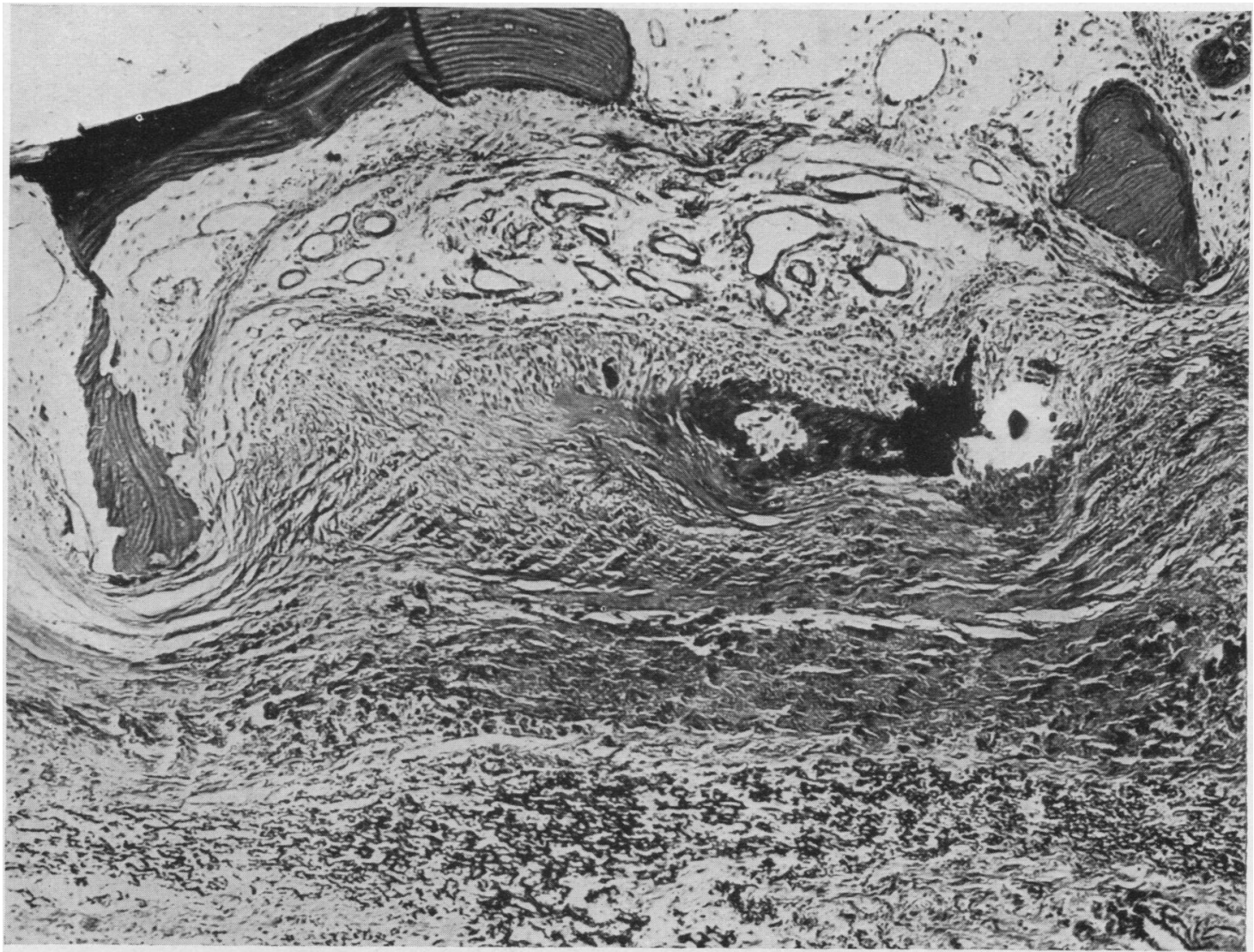

Fig. 14.-Case 16, Photomicrograph $(\times 45)$. Phosphotungstic acid haematoxylin (Mallory), showing absorbing bone spicule and osteo clasts, fibrinoid lattice work, necrobiotic nodule including necrotic bone and surrounding palisade layer, grossly hyperaemic area between this layer and the intact bone. 
sometimes more loosely, but morphologically it obviously represents nodular tissue, to which it corresponds tinctorially, when stained with haematoxylin and eosin, toluidine blue, periodic acid Schiff, silver impregnation, and Mallory's phosphotungstic acid haematoxylin. Bone spicules were largely eroded away, some remaining partly surrounded by osteoclasts, and others buttressed by fresh layers of bone.

\section{Differential Diagnosis of Sub-Achilles Swellings}

The only patient in this series who did not have rheumatoid arthritis showed calcification radiologically in the sub-Achilles swelling (Case 20, Fig. 15), and, when this was excised, it proved histologically to be a synovial chondromatosis. Other tumours and infections (e.g. tuberculosis: Blencke, 1908; Wiesinger, 1896) may of course also occur, but we have not met them. Ossification in the Achilles tendon is an occasional cause of swelling and pain (Haglund, 1928). The lesion must also be differentiated from the peritendinous cellulitis described by Raynal (1883), which is probably traumatic in origin.
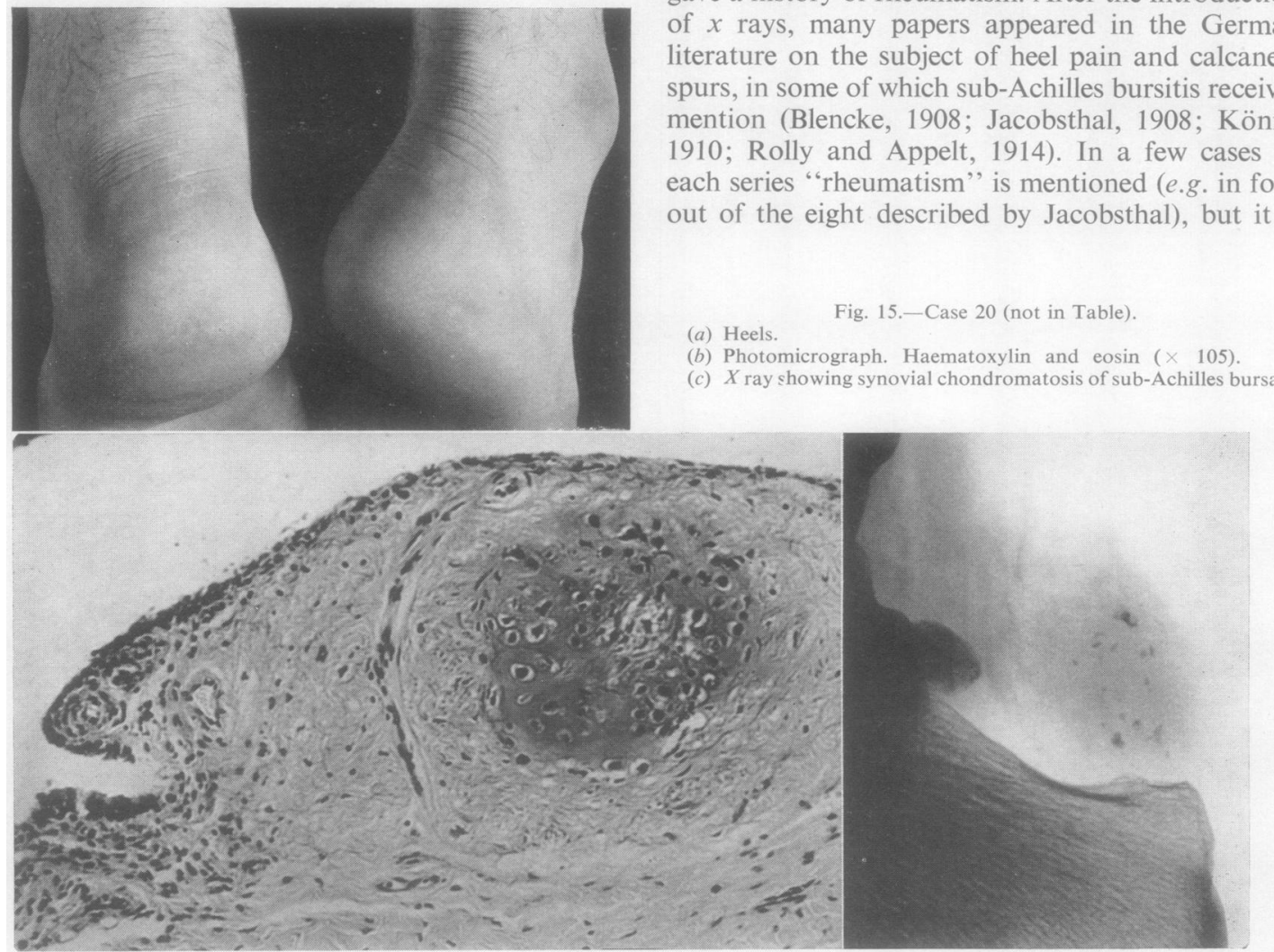

Treatment

Treatment in these patients is directed towards the्灬 generalized joint involvement. Specific local measures are sometimes necessary, particularly when these. lesions are the only ones causing symptoms. In mire cases, the sub-Achilles swelling may be treate conservatively since it usually heals in a few years without residual damage, but if it causes sever\& pain or disability (as in Cases 5, 11, and 15) it is betteg excised, which procedure led in these three patients to considerable improvement in function. The plantar lesions are probably due in part to excessive usE of the heels since they are frequently associated with metatarsal lesions. The provision of a soft pat beneath the heel or a padded ring usually gives the patient some relief.

\section{Discussion}

Sub-Achilles bursitis was first described by Albert (1893), who called it "achillodynia". Nine of his cases were later described by Rössler (1896) together with another in which the swelling was extirpated and examined. Only two of these caseso gave a history of rheumatism. After the introductio of $x$ rays, many papers appeared in the Germa $\square$ literature on the subject of heel pain and calcaneas spurs, in some of which sub-Achilles bursitis receive mention (Blencke, 1908; Jacobsthal, 1908; Köni@ 1910; Rolly and Appelt, 1914). In a few cases $0 \mathbb{\Phi}$ each series "rheumatism" is mentioned (e.g. in fou out of the eight described by Jacobsthal), but it 웅

(a) Heels.

Fig. 15.-Case 20 (not in Table).

(b) Photomicrograph. Haematoxylin and eosin ( $\times$ 105).

(c) $X$ ray showing synovial chondromatosis of sub-Achilles burs 
not possible to determine whether their patients had rheumatoid arthritis, rheumatic fever, gout, or spondylitis as we know these entities to-day. Even in the most recent publications mentioning achillodynia (e.g. Haglund, 1928; Berenwenger, 1930; or Tepper and Haspekov, 1939), the details given are insufficient to determine the type of rheumatism. In all of these older series the chief aetiological factor was thought to be gonorrhoea, followed by trauma, and a large number of other causes, including rheumatism, tuberculosis (Blencke, 1908; Wiesinger, 1896), syphilis (Schirren, 1902), influenza (Franke, 1895), gouty diathesis, etc.

The present series of lesions is, with one exception (a synovial chondromatosis), associated with and due to rheumatoid arthritis: this is not thought to be coincidental, or entirely accounted for by selection of patients. It is thought that rheumatoid arthritis is the most common cause of sub-Achilles bursitis and of erosive plantar calcaneal lesions, and that the two are often associated the one with the other.

\section{Summary}

Nineteen cases of rheumatoid arthritis with heel lesions are described clinically and radiologically. Pathological observations were made in three cases. The two lesions which not infrequently occur together are:

(i) a sub-Achilles bursitis which erodes the os calcis and finally obliterates the bursa,

(ii) an erosion of the plantar surface of the os calcis by fibrinoid-containing tissue closely resembling a rheumatoid nodule.

I am grateful to Mr. Arden who kindly referred several of these patients and allowed me to use his notes, to
Dr. Glynn and Dr. Harrison for use of pathological material, and to Mr. Fiske for the photographs.

\section{REFERENCES}

Albert, E. (1893). Wien. med. Pr., 34, 41.

Albert, E. (1893). Wien. med. Pr., 34, 41. $159,472$.

Berenwenger, P. (1930). Arch. klin. Chir., 159,
Blencke, A. (1908). Z. Orthop. Chir., 20, 363.

Dresner, E., and Bywaters, E. G. L. (1953). Unpublished observations.

Franke, F. (1895). Arch. klin. Chir., 49, 487.

Haglund, P. (1928). Acta Chir. Scand., 63, 292.

König, F. (1910). Dtsch. med. Wschr., 36, 597.

Raynal, E. (1883), Arch. gén. Méd., 152, 677.

Rössler, A. (1896). Dtsch. Z. Chir., 42, 274.

Rolly, F., and Appelt, O. (1914). Arch. klin. Chir., 105, 358.

Schirren, C. (1902). Dtsch. Z. Chir., 67, 132.

Tepper, P. A., and Haspekov, G. E. (1939). Acta med. scand., 100, 296. Wiesinger, -. (1896). Dtsch. Z. Chir., 43, 603.

\section{Lésions du talon dans l'arthrite rhumatismale \\ Résumé}

On décrit au point de vue clinique et radiologique 19 cas d'arthrite rhumatismale avec des lésions du talon. Dans trois cas on a pu faire une étude anatomopathologique. On a trouvé deux sortes de lésions survenant assez souvent ensemble:

(i) une bursite sous-achilléenne, érodant le calcanéum et finalement oblitérant la bourse,

(ii) une érosion de la surface plantaire du calcanéum par un tissu contenant une substance fibrinoïde et ressemblant beaucoup à un nodule rhumatismal.

\section{Lesiones del talon en la artritis reumatoide SUMARIo}

Se describe clínica y radiológicamente 19 casos de artritis reumatoide con lesiones del talón. En tres casos se pudo hacer un estudio anatomo-patológico. Encontráronse dos tipos de lesiones, muchas veces al mismo tiempo:

(i) una bursitis sub-aquílea causando la erosión del calcáneo y finalmente obliterando la bursa,

(ii) una erosión de la superficie plantar del calcáneo por un tejido conteniendo una substancia fibrinoide $y$ muy parecida a un nódulo reumático. 